\title{
Retraction Note to: Rainfall erosion characteristics of loess slope based on big data and internal financial control of enterprises
}

\section{Xiaofeng $Y u^{1}$}

Published online: 15 November 2021

(c) Saudi Society for Geosciences 2021

Retraction Note to: Arabian Journal of Geosciences (2021) 14: 1589

https://doi.org/10.1007/s12517-021-07960-0

The Editor-in-Chief and the Publisher have retracted this article because the content of this article is nonsensical. The peer review process was not carried out in accordance with the Publisher's peer review policy. The author has not responded to correspondence regarding this retraction.

The original article can be found online at https://doi.org/10.1007/ s12517-021-07960-0.

Xiaofeng Yu

feng2021cg@163.com

1 Gongqing College of Nanchang University,

Gongqing 332020, Jiangxi, China 